\title{
Outdoor education as a way of life
}

\author{
MANUELA VALENTINI ${ }^{1}$, PAOLA DONATIELLO ${ }^{2}$ \\ ${ }^{1,}$ Department of Humanistic Study, University“Carlo Bo", Urbino, ITALY \\ ${ }^{2,}$ Support teacher (Anthropologist) I.I.S. Panzini, Senigallia.
}

Published online: February 28, 2021

(Accepted for publication February 22, 2021)

DOI:10.7752/jpes.2021.s1072

\begin{abstract}
The lockdown, resulting from the pandemic, has clearly highlighted the need to rethink and relocate the human dimension; mutability and complexity make our reference systems precarious, making certainties now acquired waver. Education emerges in the front line with its contradictions and urgencies. It is necessary to think of school as an educational community capable of mediating and activating educational and training strategies that allows one to breathe, and have an encounter between the nerve centres of post-modernity, where awareness and re-appropriation of one's own identity emerge through forms of creativity. School, as a physical place leaves room for new territories of conquest where education in the open air appears to be the anchor of salvation.

From the analysis of the most recent studies it is clear what the benefits of outdoor education are: physical, cognitive and socio-affective. An outdoor educationexperience can stimulate a more holistic educational process: the aim of thisanalysisis to show the evidence of this opinion and observe the development of empathic and socio-relational skills to cope with a new humanism. In fact, outdoor educationisexperientialeducationthatrefers to learning by doingand allows the practice of a specific case related to a real problem in order to enhance motivation, divergent thinking and the personal handling of the proposed cognitive problem.

We do not want to present the outdoors as a temporary alternative, aimed at solving problems, but as a practice, a physical and metaphysical space to live in, a mental habit. Outdoor education should become a lifestyle, a mental form that allows us to be inside creative spaces and outside of often pre-established and stereotyped networks.

Keywords: outdoor education, inclusion, childhoodnatural setting, outdoor play, social emotional learning.
\end{abstract}

\section{Introduction}

The school, as a 'space' dedicated to learning, has shown in particular at this moment, all its criticalities. Often stiffened, immobile and crystallized, it struggles to adapt to the needs of a present in constant transformation. Complexity is the key word to unravel the thick wefts woven by a socio-global (dis)order, the result of the processes of negotiation, deconstruction and post-globalizing reconstruction typical of the planetary era, where the irreducibility of the multitude emerges (Negri\& Hardt, 2004).

What do we mean by complexity? It is the term we use when we feel confused, says Morin, in fact «complexityis a challenge to knowledge not a solution»(Morin\&Tager, 2013, p. 125). Complexity must be repositioned and rethought in the context that embodies or disembodies it in order to be reinterpreted in a holistic perspective of openness towards further suggestions. What is complex «is what cannot be reduced to a clear description, to a simple idea» (Morin\&Tager, 2013, p. 125).

Ours is a liquid society, Bauman(2011) would say, certainly kaleidoscopic where even learning processes can no longer rely on habits and stereotypes. In this multifocal and multivocal multidimensionality, objective and subjective bodies manifest themselves as a psycho-physical concretization of social actors, understood as circular autopoietic systems: we are part of the same cognitive process that we are conditioned to and which in turn conditions us, as we creep into non-neutral spaces.

We need to visit, live, inhabit other spaces, open, shared and sharable, which nevertheless will allow that physical distance that we talk about so much, that safe distance that does not however recall something atypical but simply the possibility of managing one's own body even in movement in a natural habitat, re-evaluating it, re-living it, re-detecting it and re-sharing it. The cultural reference framework in which to insert the reasons for this study and the questions it raises, and the aim of this analysis are certainly not to offer definitive answers. They allow us to calibrate future projects in a rigorous and at the same time flexible perspective.

Therefore, the aims of this paper are to solicit questions, to undermine the rigidity of a training system linked to the immutability of its situational surroundings. In such a context, the importance of promoting outdoor education emerges by giving it a new guise; that of a cultural category in which to experiment the educational methods of further and creative possibilities and planning good practices. 
The scientific literature, just a few examples, (Phyllis, 1986, Burgess \& Ernst, 2020, Wolff, Skarstein, \&Skarstein, 2020, Kinberg, 2020), has largely demonstrated the importance of outdoor education practices; part of the contributions (Fjørtoft, 2001; Federici, 1993; Valentini\& Donatiello, 2020, Apaychev et al., 2018) focused on the motor and health component, but significant, studies related to cognitive aspects are now starting to be (Zamzow\& Ernst, 2020), psycho-social (Sabet, 2018; Kumpulainen et al., 2020) and inclusive (Dunst, 2020) about outdoor orientation.

Trying to define a framework in which to place the action of outdoor education, we realize that there are many possible definitions, but: «the mostcomprehensive one seems to be, 'Outdoor educationiseducation in, and aboutthe out of doors'. Thisdefinitiontellswhere the learning takes place, the topic to be taught, and the purpose of the activity» (Phyllis, 1986, p. 2).

In the scope of outdoor education learning processesare includedthat take place in outsideareassuchas school playgrounds, meadows, and forests. «Outdoor educationwhichisalsocallededucationoutside the classroom, education out of doors, learning out of doors, outdoor learning, authentic learning in landscapes and in literature refers to an approachdirected to learning based on concrete experiences» (Bal\& Kaya, 2020, p. 168).

The livedspace plays a fundamentalrole in the development of the child. The naturalenvironmentis a rightthatcannotremainvirtualobservationbetween screens and windows, therefore, itisnecessary to educate in love, respect, care for the environment by promoting a concrete, dialogical and spontaneousexperience with nature (Valentini \& Donatiello, 2020).

Outdoor education is located in a potential space, in the transitional area between subjective and objective reality(Winnicot, 1999). It allows one to remain on the threshold, being ready to change; we must swear by the moon, for she changes constantly ${ }^{1}$. It is in this renewable and situational frontier, demarcating the self and the world, as the will to inhabit the borders, that it is realized in the negotiation of the narrative identities of each one, allowing a holistic view that can be shaped and reshaped(Cuche, 1999). The notion of boundary allows one to evoke belonging to a collective self as a production of meanings and symbols that can be shared and manipulated to determine new cognitive-relational practices and poetics.

Space, in fact, is not something defenceless, nor static, nor is it composed only of physical properties, visible or measurable, but is also constructed by our relationships, our knowledge, our illusions and is modified by our way of doing and acting, perhaps imperceptible: «in a world of pure spacethereis the world of the senses» (Bey, 2007 , p. 33). «The subjectmatter of outdoor educationis a holisticcombination of the interrelationships of all nature and the human being, attitudes for caring for the universe, and skills for utilizingnaturalresources for human survival and for leisurepursuits» (Phyllis, 1986, p. 3.)

\section{Methodology and material}

The aim of this study is to show how «an outdoor educationexperience can stimulate a more holistic educational process»(Bornais et al., 2019, p. 108), and to observe the development of empathic and sociorelational skills to cope with a new humanism.

After a scientificanalysis of the mainbibliographicreferences in the field of outdoor education, 40 papers wereselectedbased on the searchcriteria. Thesearticleswereusedas a contextual frame of reference to place the analysis in context. The resultsobtained led to a more specificanalysis of 20 sources, asthey are more current and similar to the purposes of the research.

Following bibliographic research and historical theoretical references, protocols selected on the basis of their relevance to the established inclusion, the following criteria have been taken into consideration:

- topic, outdoor education, social emotional learning in outdoor activity, physical and cognitive development linked to schools' outdoor experiences, (Keywords: outdoor education, childhood natural setting, emotional learning);

- $\quad$ age group, corresponding to the age of development, but the opinions of adults, especially teachers, are also being investigated;

- $\quad$ release date, this study, after taking into consideration a basic general bibliography starting from the last 20 years, has mainly focused on the contributions of the publications of the most recent years by analyzing the protocols from 2018-2020.

The main search engines used for the collection of studies are: JPES, Springer link, Eric, MDPI, Google Scholar, PubMed.

The aim of this bibliographic research is to approach the topic of outdoor education in a transversal way, in order to observe it from different angles. In fact, the researchers who conducted the studies come from different geographical and educational backgrounds: in order to offer a global overview the authors are North American, Hungarian, Italian, Slavic, Portuguese, Turkish, Slovenian, Finnish and English.

The survey methods used by the researchers are, bibliographic analysis, measurement scales (Zamzow\& Ernst, 2020; Burgess \& Ernst, 2020) field work and questionnaires (Hunter et al., 2019, Bal and Kaya, 2020).

\footnotetext{
${ }^{1}$ Freelyinspired by Shakespeare
} 


\section{Results: evidence analysis}

In today's sedentary societies the relationship with the environment as a tool of knowledge isincreasingly lost: obesity, hypokineticsyndrome, asthenia, attention deficit, loss of coordinating and conditional functional abilities such as strength, speed, resistance, are the obvious expression of bad lifestyles of our metropolitan children (Federici, 2015, p. 106). Apaychev et al. (2018) show that outdoor motor activity has a beneficialeffect on health (resistance to stress, prevention of cardiovasculardiseases). «The risks, a physical and mental level, of a sedentary lifestyle are many and move progress towards the implementation of experimental programs, aimed at developing motor engines in the open air, understood as the re-appropriation of physical and mental spaces capable of sensitizing the child towards freedom which implies respect, autonomy and the ability to relate» (Valentini\& Donatiello, 2019, p. 103), the environment, where the needs of human beings are born and consumed, is to be considered as a sort of open book.

«Over time, approaches to outdoor educationhavechanged from a primary focus on personal development to otherareas of development, in line with societalpriorities and currentunderstandings of howstudentslearn best» (Sabet, 2018, p. 15).

Jenna Zamzow and Julie Ernst (2020)utilized the Minnesota Executive Function Scale «to quantitativelyexplore the influence of nature preschools on executive function skills»(Zamzow\&Ernst, 2020, p. 6). The study showed that the level of development of executive functions is the same in both groups, but«climbing trees, playing in the snow, building forts, and stomping in mudpuddles are ...healthier forms of interventions in support of executive function development» (Zamzow\& Ernst, 2020, p. 14). Federici (1993) states that motor activity in the natural environment is, at school level, symptomatic of an active and interdisciplinary school.

Eva Burgess and Julie Ernst (2020, p. 17)utilized the Penn Interactive Peer Play Scale and Preschool Learning Behaviors Scale, showing that nature preschools may be having a significant positive influence on peer play behaviors as well as on all dimensions of learning behaviors: the nature preschool movement, is grounded in a desire to foster connection to the natural world while also supporting important developmental processes and school readiness.

«The benefits of being out-of-doors go beyondsimplygettingexercise to includingemotional, cognitive, and social benefits» (Sabet, 2018, p. 12).

Crudeli et al. (2012), inthe survey carried out with the children in the nursery revealed the importance of outdoor education also understood this as the possibility of taking risks and overcoming one's own limits, avoiding the restrictions and excessive controls often dictated by rigid spaces and places. «Outdoor activities affordchildren more freedom to explorenovel settings compared to indoor activities» (Dunst, 2020, p. 35). In factthe impact of nature and the outdoors on a child'sdevelopmentbeginswithin the first year of life,stateBarford et al. (2020).

BurrissandBurriss(2011) exploring the potential of the school outdoor environment demonstrate «that play contributes to children's social, emotional, cognitive, and physicaldevelopment» (Burriss\&Burriss, 2011, p. 10).

Hunter et al. (2019), using ethnographically grounded data collection, focused upon the perspectives of adults about outdoor play and learning for young children, showing that «whileteachersmaintain a strong preference for child-led learning, the changing outdoor spacerequiresincreasedadult-led activities and intentionalenvironmentaleducation goals and training» (Hunter et al., 2019, p. 34).

Hawxwell (2019)explored the perceptions of outdoor learning held by trainee teachers «theyweregenerally positive butalsoappeared to be apprehensive and cautiousaboutspecificelementsrelated to outdoor learning» (Hawxwell, 2019, p. 106).

Baland Kaya (2020) in their study aim to reveal the opinions of teachers about education and students in forest schools, the results confirm the claims made by Borradaile that the forest school «hasprovable and multiple effects on children'sphysical, social and emotionaldevelopment... the teacherssaythat the childrenwhohaddifficulties in expressingthemselves and whowereafraid to speakhaveovercomealltheseproblems and supports thattheir self-confidence hasdeveloped» (Bal\& Kaya, 2020, p. 176).

Outdoor education positively influences the development of creativity and divergent thinking. «Narrative analysisrevealshow the children'saugmentedstorying in nature wasperformedthroughplayful, affective, and sensuous, identity, cultural, and criticalliteracies, whichwereimaginativelyconstructedintobeingat the nexus of theirsensed reality and fantasy» (Kumpulainen et al., 2020, p. 1). For exampleKinbergduring a workshop Writing in Nature for students (ages 10-12)foundthatusing a naturalenvironment for writing labs is an effectivereal-life setting for increasing engagement time, teachingcontent, and writing skills developmentfound that using a natural environment for writing labs is an effective real-life setting for increasing engagement time, teaching content, and writing skills development (Kinberg, 2020).

The narrative, is a bit like playing inside the stories, allowsyou to tell yourselfeventhroughgestures and movements, the protagonistisour body thatamplifies the imagination, fantasy, musicality, spontaneity (Valentini \& Santi, 2007).

Outdoor education is effective, not only in childhood, but also in higher education, Leadbetter et al. (2019)demonstrated that outdoor learning experiences in higher education (HE) offer the opportunity for emotional, cognitive and learning development. Furthermore,Bornais et al. (2019),realized that the experiences 
were as beneficial for facilitators and for participants. «Manysimilarthemeswerenoted by Ashworth (2017), including feelings of connectedness, the value of learning outdoors, experiences and personal development. Learning isinfluenced in fundamental ways by the context in whichit takes place» (Bornais et al., 2019, p. 115).

Dunst (2020)described the benefits of nature informal learning, also as a tool for inclusion. A case study participants included 115 children with identified disabilities and 91 children without disabilities. «Findings from the present study nonetheless indicate thatwhenoutdoors, youngchildren with and withoutdisabilities or delays, participate in a host of different nature-related activities wherethose activities provide the children with manydifferentkinds of learning opportunities» (Dunst, 2020, p. 35).

\section{Discussion: benefit, meaningful learning, creativity and empathy}

The health and physical-motor ${ }^{2}$ and cognitive benefits havebeenwidelydemonstrated, so the mostrecent literature focuses on the socio-cognitive potential of outdoor.Outdoor educationis, also,referred to a processinvolvingdirect learning experiences (Phyllis,1986, p.3). It therefore fosters meaningful and experiential learning: «the processwhereby knowledge iscreatedthroughtransformation of experience» (Kolb, 1984, p. 38).

Cognitive benefits include «more opportunities for independentproblem solving, especially through manipulating objects» (Sabet, 2018, p. 12) in order to reach the understanding meant as deep knowledge that starts from the basic knowledge of the pupils, which are not tabulae rasae, but agents and co-builders of an interpreted and negotiated knowledge.

«The more real-life thosecontexts are, the more meaningfulthey are for student. In fact, researchhassuggested a connection betweenauthentic learning contexts and problem-solving activities, and meaningful learning outcomes» (Kinberg, 2020, pp. 1-2).

Outdoor educationisexperientialeducationthatrefers to learning by doing (Phyllis, 1986, p. 7)and allows the practice of a specific case related to a real problem in order to enhance motivation, divergent thinking and personal handling of the proposed cognitive problem.

Outdoors encourages the children to be more creative(Hawxwell, 2019, p. 111), fosters lateral thinking and a deep restructuring of the perceived gestalt problem, through the understanding or intuition of functional and spatial relations between the present objects.

«Children, outside in nature, are likely growing in their affective connection to the natural world. With these deepened connections to the natural world alongside their ability to plan and execute goal-oriented behaviors, the findings from this study provide another opportunity for thinking about young children's contributions to a more sustainable future» (Zamzow\& Ernst, 2020, p. 14).

The emotional benefits of being outdoors include increased confidence and an increased ability to cope with stress and even trauma Saber, 2018, p. 12), this allows one to work on one's resilience, understood as the resumption of a possibledevelopment after a traumaticlaceration (Malaguti, 2005, p. 16)by activating appropriate coping strategies. «Children develop a sense of place whentheyconnect with theirlocal communities and outdoor environment»(British Columbia,2019, p. 21).Exploring nature together develops the perspective-taking(Wolff et al., 2020, p. 9),refers to a child'sability to simultaneouslydifferentiatetheirownperspective from another and furtherrecognizethat the other'sperspectivemay be different from theirown (Burriss\&Burriss, 2011, pp. 23), cooperation, group thinking, teamwork (Cooley, 2014), self-confidence (Crudeli et al., 2012), empowerment. Especially free outdoor play, ifdeveloped from childhood, enhancescooperative and socio-affective skills (Duque, I., Martins, F.M.L. \&Clemente F-M.,2016):«outdoor area servesas a naturalenvironment to nurtureprosocialbehavior and diminishbullying; educators help childreneffectivelyinteract with one another»(Burris\&Burris, 2011, p. 3). Outdoor educationhas«the potential to amplify the group dimension by allowing for shared and reflective learning» (Leadbetter, 2019, p. 69).

The sensory-motorstimulations in the naturalenvironment, according to Federici (2015) encourage learning in the child, improve peer work and collaboration, reducingantisocial and deviantbehaviors in school contexts, facilitate the development of leadership, problem solving skills andhave positive effects on motor skills andlanguage skills (Federici, 2015, p. 110).

Natural setting are associated with, «greater feelings of revitalisation and positive engagement»(Bornais et al., 2019, p. 113).

Outdoor education «keeps the sense of curiosityalive, presents a unique learning environment and that the studentseducatedhereasindividualswhohave self-confidence, are inquisitive, creative, solution-oriented, learning by doing and with a developedsense of responsibility» (Bal\& Kaya, 2020, p. 167), moreover, outdoor educationhassuch a strong potential to influence the choices made asadults (Dobay, B., Bánhidi, M. \&Šimonek, J., 2018).

\section{Conclusion}

From the analysis of the most recent studies it is clear what the benefits of outdoor education are: physical, cognitive and socio-affective. Furthermore, the outdoors provide an excellent environment to reflect on

\footnotetext{
${ }^{22}$ For further information Valentini M.\& Donatiello P. (2020).Educazione ambientale e motoria in età evolutiva. Per una pedagogia del movimento in natura. Roma: Anicia.
} 
interdisciplinarity, partly because of the nature of the setting and the varied backgrounds of the participants (Bornais et al., 2019, p. 110). «The general aim of 21st century skills isthatlearners, beingwellversed in learning-, literary- and life-skills, beingable to identify, engage and solve a host of professional and personal challenges in the workplace of the future» (Wolff et al., 2020, p. 6).

The school should foster cognitive flexibility, the process of cultural construction of caring thinking(Lipman, 2003, p. 130)which derives from emotional thinking and develops through openness to creative thinking, but often, unfortunately, it fails to grasp ecological thinking because it is difficult to free oneself from beliefs rooted in us since childhood(Morin\& Pasqualini, 2007, p. 59).«Learning experiencesthatallow for imagination can support children to steer clear of fixed mind-sets and developthosethat are flexible and open ... Invitingstudents to use theirimaginationmeansinvitingthem to seethingsotherthan the way they are» (Yanko\&Yap, 2020, p. 262). «Children need to becomefamiliar with nature in authenticenvironments, so thatthey are able to build emotional bonds with nature. Theyalsoneed to feelthatthey are competent, active agents in theirownlives» (Wolff et al., 2020, p. 13).

It is necessary to think of the school as an educational community, open also to the wider human and civil community (Annali, 2012, p. 20), to activate breathing space between the neuralgic nodes of post-modernity, where re-appropriation emerges through clandestine forms of creativity.

Webelievethat«outdoor educationis a continual educational experience. Itisnot just one field trip, 1 week at outdoor school... Itmustbe taughtatalllevels and pursuedthroughout life» (Phyllis, 1986, p. 10).

Outdoor education should become a way of life, a form of mind that allows one to be «Withinfractaldimensionsinvisible to control cartography» (Bey, 2007, p. 18).

It is a matter of acting as corsairs occupying empty spaces on the map, appropriating those no-man's-lands like a pirate utopia(Bey, 2007, p. 38)aimed at creating communities that use music as an organizational principle because «ifIcan't dance it'snotmyrevolution»said Emma Goldman.Every change is a revolution itself and the next revolution should be: outdoors as a way of life.

\section{References}

Annali della Pubblica Istruzione. (2012). Indicazioni nazionali per il curricolo della scuola dell'infanzia e del primo ciclo d'istruzione. Firenze: Le Monnier.

Apaychev, O. et al. (2018). Fitness correction of men using an "outdoor activity". Journal of PhysicalEducation and Sport, 18(4).

Bal, E. \& Kaya, G. (2020). Investigation of Forest School Concept by Forest School Teachers' Viewpoints. International Electronic Journal of EnvironmentalEducation,10 (2).

Barfod, K., Stevenson, M.P. \&Bentsen, P. (2020). Outdoor Learning in EarlyChildhood. In: Peters M. (eds) Encyclopedia of TeacherEducation. Springer, Singapore. https://doi.org/10.1007/978-981-13-1179-6 360-1

Bauman, Z. (2011). Modernità liquida. Bari: Laterza.

Bey, H. (2007). TAZ. Milano: Shake edizioni.

Bornais, J.A.K. et al. (2019). Decade of OutdoorsExperiential Workshops: Facilitator Reflections and Tips. CollectedEssays on Learning and Teaching, vol. XII.

British Columbia. (2019).Early Learning Framework. British: Columbia.

Burgess, E. \& Ernst, J. (2020). Beyond Traditional School Readiness: How Nature Preschools Help Prepare Children for Academic Success. The International Journal of EarlyChildhoodEnvironmentalEducation, 7(2).

Burriss, K.G. \&Burriss, L. (2011). Outdoor play and learning: Policy and practice. International Journal of Education Policy and Leadership, 6(8).

Cooley, S.J. et al. (2014). Introducing the use of a semi-structured video diary room to investigate students' learning experiencesduring an outdoor adventure educationgroupwork skills course. HigherEducation, 67(1).

Crudeli, F., La Serra, C. \& Monti, F. (2012). Outdoor Education. Idee e questioni, Aprile.

Cuche, D. (1999). La noción de cultura en lascienciassociales. Buenos Aires: Ed. NuevaVisión.

Dobay, B., Bánhidi, M., Šimonek, J. (2018). Effects of outdoor education on travelinghabits of adults in Slovakia and Hungary. Journal of PhysicalEducation and Sport, 18(2).

Duque, I., Martins, F-M-L, Clemente F-M. (2016). Outdoor play and interaction skills in earlychildhoodeducation: approaches for measuringand using social network analysis.Journal of PhysicalEducation and Sport, 16(4).

Dunst, C.J. (2020). Everyday Learning Opportunities of Young Children With and WithoutDevelopmentalDisabilities or Delays. International Journal of EarlyChildhoodEnvironmentalEducation, 7(3).

Federici, A. (1993). Attività motorie in ambiente naturale. Idee, proposte ed esperienze. Urbino: Montefeltro.

Federici, A. (2015). Attività motoria in ambiente naturale: una scelta per la vita. In RELAdEI, 4(3).

Fjørtoft, I. (2001). The Natural Environment as a Playground for Children: The Impact of Outdoor Play Activities in Pre-Primary School Children. EarlyChildhoodEducation Journal, 29(2).

Hawxwell, L. (2019). Youonlyneed a potato peeler and tarpaulin - Perceptions of outdoor learning from PrimaryEducationTrainees. TeacherEducationAdvancement Network Journal University of Cumbria, 11(1). 
Hunter, J. et al. (2019). Balancing outdoor Learning and Play: AdultPerspectives of TeacherRoles and Practice in an Outdoor Classroom. The International Journal of EarlyChildhoodEnvironmentalEducation, 7(2).

Kinberg, M. (2020). Real-Life Nature-BasedExperiencesas Keys to the Writing Workshop. Networks: An Online Journal for TeacherResearch, 22(1).

Kolb, D.A. (1984). Experiential learning: Experience as the source of learning and development. NJ: PrenticeHall.

Kumpulainen, K. et al. (2020). Children'sAugmentedStorying in, with and for Nature. Education Sciences, 10(6), 149.

Leadbetter, P., Bussu, A. \& Richards, M. (2019). Emotive outdoor learning experiences in HigherEducation: Personal reflections and evidence. PsychologyTeaching Review,25(1).

Lipman, M. (2003). Thinking in Education. Cambridge: University Press.

Malaguti, E. (2005). Educarsi alla resilienza Come affrontare crisi e difficoltà e migliorarsi. Trento: Centro Studi Erickson.

Morin, E. \& Pasqualini, C. (2007). Io, Edgar Morin: una storia di vita. Milano: Franco Angeli.

Morin, E. \&Tager, D.K. (2013). Il mio cammino. DjénaneKarehTager intervista Edgar Morin. Roma: Armando Editore.

Negri, A. \& Hardt, M. (2004). Moltitudine, Guerra e democrazia nel nuovo ordine imperiale. Milano: Rizzoli.

Phyllis, F. (1986). Outdoor education: definition and philosophy. ERIC Digest. Las Cruces, NM: ERIC Clearinghouse on Rural Education and Small Schools.

Sabet, M. (2018). Current Trends and Tensions in Outdoor Education. BU Journal of Graduate Studies in Education, 10(1).

Valentini, M. \& Santi, G. (2007). Esprimi-amo le emo-azioni. Atelier ludico-motorio nella scuola dell'infanzia. Perugia: Margiacchi-Galeno.

Valentini M. \& Donatiello P. (2019). Ambiente e movimento nella pluridimensionalità educativa. Ricerche pedagogiche, Anno LIII, n. 212-213, luglio-dicembre.

Valentini M.\& Donatiello P. (2020). Educazione ambientale e motoria in età evolutiva. Per una pedagogia del movimento in natura. Roma: Anicia.

Winnicott, D. (1999). Playing and Reality. London: Routledge.

Wolff, L-A, Skarstein, T.H. \&Skarstein, F. (2020). The Mission of EarlyChildhoodEducation in the Anthropocene. EducationSciences, 10(27).

Yanko, M. \&Yap, P. (2020). A Symbiotic Link Between Music, Movement, and Social Emotional Learning: Mindful Learning in EarlyLearners.LEARNingLandscapes, Spring, 13.

Zamzow, J. \& Ernst, J. (2020). Exploring Executive FunctionGrowth in Nature Preschools. The International Journal of EarlyChildhoodEnvironmentalEducation, 7(2). 